\title{
ANALYSIS OF THE POSSIBILITY OF APPLYING THE MAINTENANCE SYSTEM BASED ON RELIABILITY BY COMPARATIVE APPRECIATION OF THE BRAKING INSTALLATION
}

\author{
Ioan VIRCA, Vasile CĂRUȚAȘU \\ "Nicolae Bălcescu" Land Forces Academy, Sibiu, Romania \\ virca_ioan@yahoo.com, v.carutasu@yahoo.com
}

\begin{abstract}
Analysing the current maintenance system, one can obviously notice a disadvantage to be found in all the cases in which the maintenance activities prove useless, not resulting in finding the flaws or the conditions leading to them, the verified equipment being declared as functioning well. Thus, it becomes indispensable that a rapid and efficient strategy should be implemented for the diagnosis of the component parts of the vehicles, the maintenance based on reliability respectively, which constantly monitors the evolution of parameters so that the permanent state of the vehicle is made known, as well as the necessary maintenance activities. As such, the maintenance based on reliability promotes an efficient policy of the maintenance activities throughout the period of using the vehicle, all the expenses being offset by reducing the maintenance costs through the decrease of the immobilisation time and the number of repair operations. The paper deals with a new approach of the aspects related to the maintenance system of vehicles, relying on mathematical statistics which allows for modelling the strategies likely to be applied within the system. The results of a mathematical approach should not be neglected since the future strategies of managing the maintenance processes of the technical systems cannot be based on simple empirical reasoning, which has most often proved costly.
\end{abstract}

Keywords: maintenance, maintenance strategies, efficiency, vehicles, braking installation.

\section{Presentation of the vehicle type for study and of the braking installation}

The DAC 444T truck is fitted with two motor axles and the DAC 665T is equipped with three axles; for both models the front axles are provided with a pneumohydraulic braking installation while the rear axles with a pneumatic braking installation.

The functioning of the braking system at optimum parameters is extremely important because it ensures the capacity of promptly and efficiently responding to the commands of the driver and the possibility of completely monitoring the speed and acceleration during exploitation.
Any truck is equipped with a service braking installation and an auxiliary or parking braking installation. The servicebrake: activates all the vehicle wheels, its charateristics being promptitude, efficiency and accuracy. The parkingbrake: its role is that of immobilising the parked/stationary truck and of ensuring the vehicle braking when the service brake is out of order. It acts on the same braking mechanisms like the ones at the wheels of the rear axles. Each installation is made up of the mechanism activating the brake and the proper braking mechanism in the wheels. 
Additionally, the two analysed models are provided with an engine brake and an emergency brake. The engine brake allows the movement of the truck at a corresponding speed when going down the slopes, without being necessary to use the service brake. The emergency brake is hydraulic and works only on the wheels of the front axle, having the pressure obtained from the central pump of the clutch in the situations in which the other brakes stop working. Being used very rarely, the present study do not take them into consideration.

The component elements of the braking installation for the vehicle with three axles are presented in figure no. 3 and for the model with two axles the installation is similar to the first, not taking the third axle into consideration (figure no. 1).

Circuit I is composed of:

- air reservoir I;

- brake valve with two circuits;

- relay valve of the service brake;

- double brake cylinders with an accumulation arc;

- wheel brake.

Circuit II consists of:

- air reservoir II;

- brake valve with two circuits;

- pneumatic servomechanism;

- wheel brake.

2.Calculation of reliability for the braking installation of the DAC 444T truck

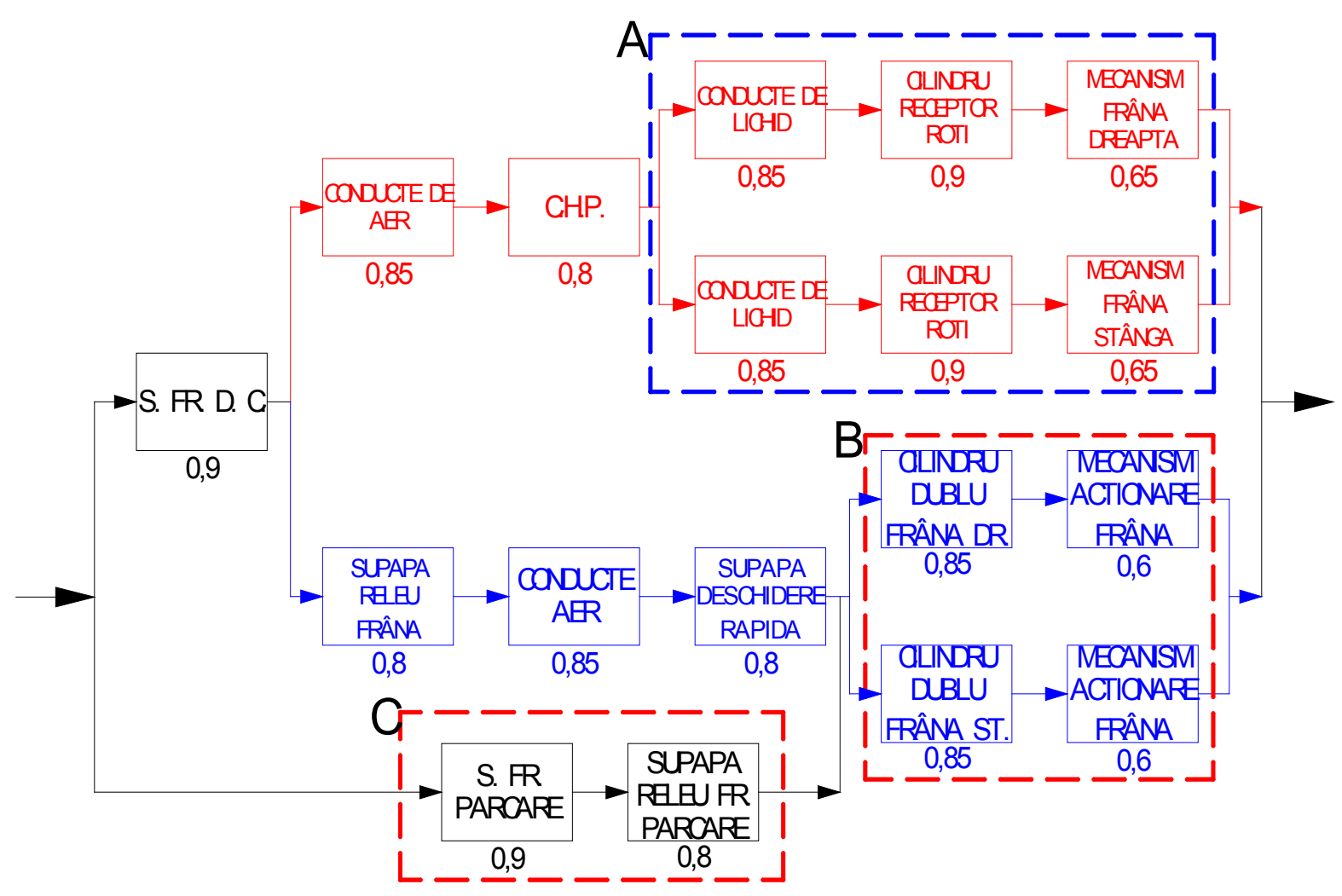

Figure 1: Logical reliability chart of a braking system with two axles

Methods of calculation of block chartsreliability:

1. Reliability of block A:

$\mathrm{R}_{A 1}=\mathrm{R} A 2=0,85 \cdot 0,9 \cdot 0,65=0,497$

$\mathrm{R}_{A}=1-(1-0,49) \cdot(1-0,49)=0,74$
2. Reliability of block B:

$\mathrm{R}_{B I}=\mathrm{R} B 2=0,85 \cdot 0,6=0,51$

$\mathrm{R}_{B}=1-(1-0,51)(1-0,51)=0,76$ 
3. Value of reliability function for service brake:

$\mathrm{R}_{\text {serv.brake }}$

$0,9 \cdot[(1-(1-0,85 \cdot 0,8 \cdot 0,74)(1-0,8 \cdot$

$0,85 \cdot 0,8 \cdot 0,76)]=0,63$

4. Value of reliability function for parking brake $\mathrm{C}$ :
$\mathrm{R}_{\text {park brake }}=0,9 \cdot 0,8 \cdot 0,76=0,54$

5. Value of reliability function for the whole braking system:

In figure no. 2 the simplified logical chart of reliability is presented:

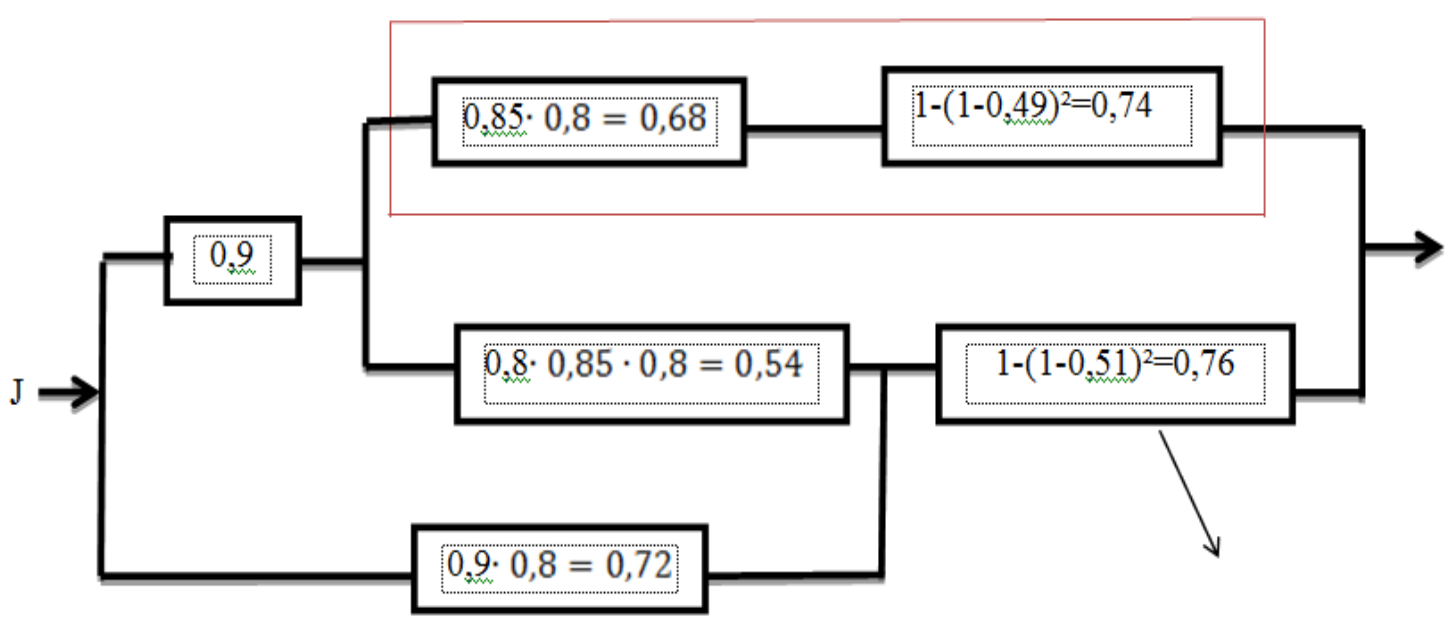

Figure 2: Logical reliability chart of a braking system with two axles, simplified version

a) State $s=1 / j=1$

$s=1$ symbolizes the state of good functioning of the system;

$j=1$ state of maximum reliability of component $j$;

$\mathrm{j}=0$ break down state of component $j$.

$\mathrm{R}_{\mathrm{b}}=0,68 \cdot 0,74=0,5$

$\mathrm{R}_{\text {fr serv }}=09 \cdot[1-(1-0,5)(1-0,54)]=0,69$

$\mathrm{R}_{(\mathrm{s}=1 / \mathrm{j}=1)}=1-[(1-0,69)(1-0,72)]=0,92$

b) $\quad$ State $s=1 / j=0$

$\mathrm{R}_{(\mathrm{s}=1 / \mathrm{j}=0)}=0,9 \cdot 0,68 \cdot 0,74=0,45$

Reliability of the system (the formula of total reliability is applied):

$\mathrm{R}_{\text {sist. }}=\mathrm{R}_{(\mathrm{s}=1 / \mathrm{j}=1)} \cdot \mathrm{Rj}+\mathrm{R}_{(\mathrm{s}=1 / \mathrm{j}=0)} \cdot(1-\mathrm{Rj})$, în care:

$\mathrm{R}_{\text {sist. }}=0,92 \cdot 0,76+0,45 \cdot(1-0,76)=0,79$.

3. Calculation of reliability for the braking installation of the DAC 665T. Methods of calculation of block charts reliability

1. Reliability of block A:

$\mathrm{R}_{\mathrm{A} 1}=\mathrm{R}_{\mathrm{A} 2}=0,85 \cdot 0,9 \cdot 0,65=0,49$

$\mathrm{R}_{\mathrm{A}}=1-(1-0,49)^{2}=0,74$
2. Reliability of blocks $\mathrm{B}$ and $\mathrm{C}$ :

$\mathrm{R}_{\mathrm{B} 1}=\mathrm{R}_{\mathrm{B} 2}=\mathrm{R}_{\mathrm{C} 1}=\mathrm{R}_{\mathrm{C} 2}=0,85 \cdot 0,6=0,51$

$\mathrm{R}_{\mathrm{B}}=\mathrm{R}_{\mathrm{C}}=1-(1-0,51)(1-0,51)=0,76$

$\mathrm{R}_{\mathrm{X}}=1-\left(1-\mathrm{R}_{\mathrm{B}}\right)\left(1-\mathrm{R}_{C}\right)=1-0,24^{2}=0,95$

3. Reliability of block $D$ :

$\mathrm{R}_{\mathrm{D}}=0,9 \cdot 0,8=0,72$

4. Value of reliability function for service brake:

$\mathrm{R}_{\text {serv.br.(front) }}=0,85 \cdot 0,8 \cdot 0,74=0,5$

$$
\begin{aligned}
R_{\text {serv.br.(rear })=} & 0,8[1-(1-0,85 \cdot 0,8 \cdot 0,76)(1- \\
& 0,85 \cdot 0,8 \cdot 0,76)]=0,6 \\
\mathrm{R}_{\text {serv. br. }}= & 0,9 \cdot[1-(1-0,5)(1-0,6)]=0,72
\end{aligned}
$$

$\mathrm{R}_{\text {park.br }}=\quad 0,9 \cdot 0,8 \cdot[1-(1-0,76)(1-$

$0,76)]=0,68$

5. Value of reliability function for the whole braking system:

Simplifying the logical chart (figure 4), results: 
a) state $\mathrm{s}=1 / \mathrm{j}=1$

$\mathrm{R}_{\mathrm{C}}=0,8 \cdot[1-(1-0,68 \cdot 0,76)(1-0,68)]=0,68$

Rserv.br. $=0,9 \cdot[1-(1-0,54)(1-0,68)]=0,77$

$\mathrm{R}_{(\mathrm{s}=1 / \mathrm{j}=1)}=1-[(1-0,77)(1-0,72 \cdot 0,76)]=0,9$

b) state $s=1 / j=0$
$\mathrm{R}(s=1 / j=0)=0,9 \cdot[1-(1-0,54)(1-0,68)]=0,77$

Reliability of the system (the formula of total reliability is applied):

$\mathrm{R}_{\text {syst }}=0,9 \cdot 0,76+0,77 \cdot 0,23=0,85$

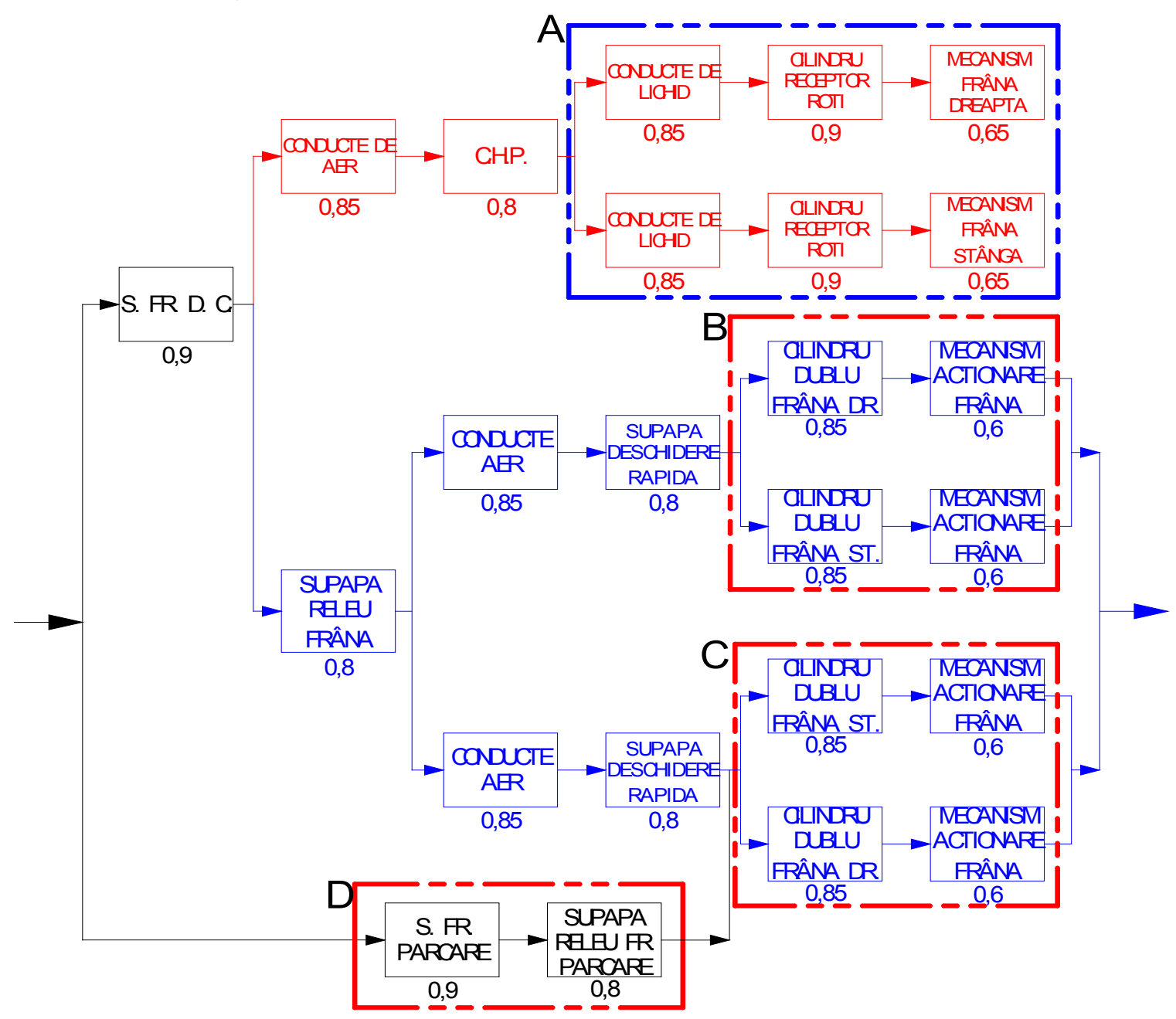

Figure 3: Logical reliability chart of a braking system with three axles

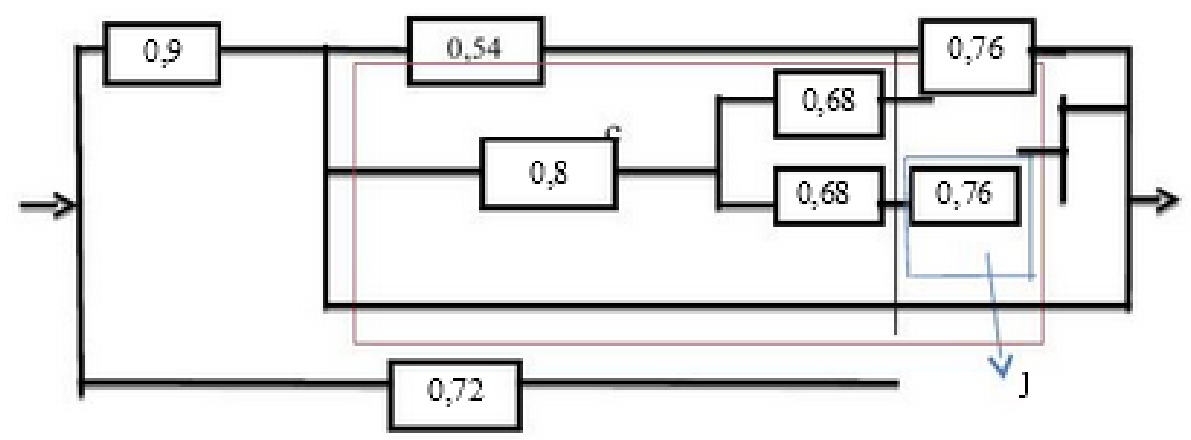

Figure 4: Logical reliability chart of a braking system with three axles, simplified version 
4. Highlighting results

\begin{tabular}{|c|c|c|}
\hline $\begin{array}{c}\text { Type vehicle/ } \\
\text { Parameters }\end{array}$ & DAC 444T & $\begin{array}{c}\text { DAC } \\
665 T\end{array}$ \\
\hline $\mathrm{R}_{\text {serv.br. }}$ & 0.63 & 0.72 \\
\hline $\mathrm{R}_{\text {park.br. }}$ & 0.54 & 0.68 \\
\hline $\mathrm{R}_{\text {syst }}$ & 0.79 & 0.85 \\
\hline
\end{tabular}

Values of reliability for installations and for the whole system are presented for the comparative analysis in table 1 , likewise presented in the next graph (figure 5).

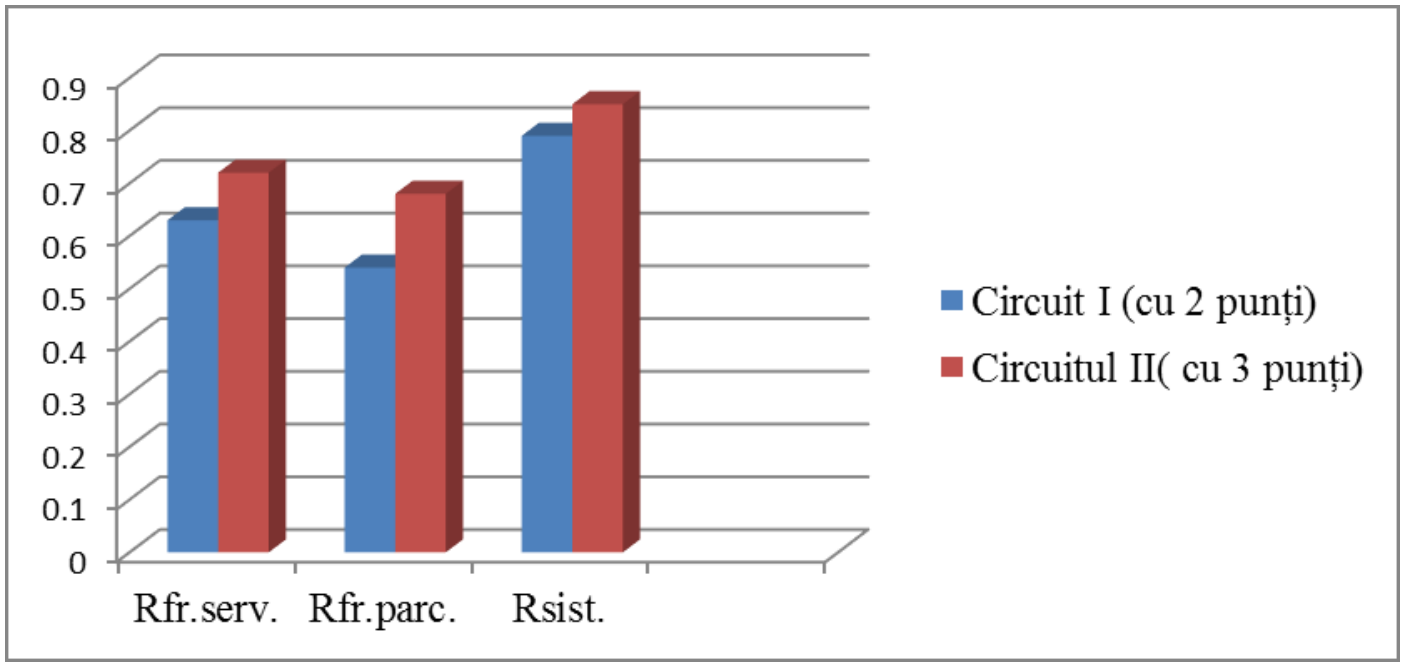

Figure 5: Graphical representation of reliability for each vehicle

\section{Conclusions}

- in the truck with 2 axles the reliability is lower in value of only 0.63 on the service brake due to the multitude of elements linked in a series. Even if the two front-rear braking circuits start from the brake valve in parallel, a part of the component elements on each circuit are displayed in a series (as mentioned above), thus affecting reliability. This type of activating the service brake is beneficial in the situation in which the braking system of the front wheels is interrupted due to pneumo-hydraulic causes, benefitting from the pneumatic reserve on the wheels of the rear axle, which is named the redundancy of the systems in the specialized literature;

- reliability is higher for the trucks with three axles, of 0.72 , due to the parallel disposition of the braking circuits of the two rear axles. This is dictated by the need to ensure braking at least on one of the axles in the situation in which the other breaks down; related to the larger number of components, the reliability of the whole system is higher, of 0.85 , compared to 0.79 for the trucks with two axles;

- after representing the functional charts of the main components of the braking installation, there have been ascertained the values of the reliability function, determined by the probability rate, as follows: 0.79 for DAC 444T and 0.85 for DAC $665 \mathrm{~T}$ respectively. This demonstrates the fact that it is imperative that any detail be known which can highlight the way in which the reliability of a component of the system can have an impact on the whole activity of the system.

In conclusion, the combined redundant systems have the advantage of a higher reliability.

As a result of the calculations, maintaining the reliability of the constructive components and assemblies can be achieved by carrying out looking forward maintenance operations of the type that is based on reliability. 


\section{References}

[1] Bayer, M., Fiabilitatea şi mentenabilitatea sistemelor, Editura Bren, Bucureşti, 1999.

[2] Băjenescu, I., Fiabilitatea sistemelor tehnice, Editura Matrix Rom, București, 2003.

[3] Bandrabur, C., Burlacu, G., Dăneț, N., Duminică, T., Fiabilitatea, mentenabilitatea și disponibilitatea sistemelor tehnice, Ed. Matrix Rom, București, 2011.

[4] Babuș, S., Brezan, I., Florea, D., Mitu, I., Compunerea și caracteristicile constructive ale autocamioanelor DAC 665 Tși DAC 665 G.

[5] Hiatt B., Cele mai bune practici în mentenanţă, Ref.doc. MI 113 - NOT $\breve{A} T E H N I C \breve{A}$, 2011.

[6] Roşca P., Strategii de mentenanţă aplicate în Armata României în Management şi tehnologii avansate în sistemele logistice - studii şi cercetări, authors Bârsan G., Petrişor S. M., Badea D., Editura Academiei Forţelor Terestre "Nicolae Bălcescu", Sibiu, 2011, pp. 117124. 